\title{
BRIEF
}

\section{Leadership Development APPE for Fourth-Year Pharmacy Students}

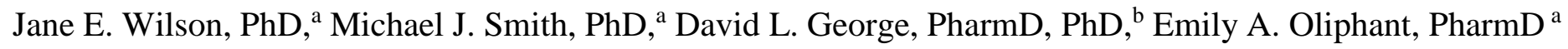 \\ ${ }^{a}$ University of Oklahoma, College of Pharmacy, Oklahoma City, Oklahoma \\ ${ }^{\mathrm{b}}$ Pharmacy Co-Owner, Creative Care Pharmacy, Edmond, Oklahoma
}

Corresponding Author: Michael J. Smith, University of Oklahoma, College of Pharmacy, 1110 N. Stonewall Ave Oklahoma City, OK 73117. Tel: 405-271-6598. Email: michael-smith@ouhsc.edu

Submitted August 23, 2020; accepted February 10, 2021; ePublished February 2021

\begin{abstract}
Objective. Describe development and current structure of an advanced pharmacy practice experience (APPE) in leadership.

Methods. Our leadership APPE evolved from mostly content-oriented delivery to an experiential offering by identifying and implementing rich practical leadership experiences over time. After five years of developing and refining the APPE, faculty coordinators sought student feedback on the current leadership rotation beyond using the standardized APPE evaluation students complete at the end of rotations. Data were analyzed and reported as means of agreement for quantitative items, and open-ended responses were analyzed by latent thematic analysis.

Results. Current APPE topics include PhotoVoice, Power of Full Engagement, What's Your Passion, Transformational Leadership, Speech Acts, a Mindfulness Retreat, PeoplePack Dynamics, a rowing experience at an Olympic training facility, and more. Overall, students positively agreed with all evaluation items. Items with highest mean agreement included: early course concepts were reinforced in the rotation; relevance of the rotation to one's career; rotation objectives facilitated learning; and a variety of teaching methods helped in applying knowledge to future practice. Analysis of comments regarding the rotation overall identified three main themes of Gratitude, Development, and More Connection, along with various subthemes.

Conclusion. An APPE elective with a primary purpose of leadership training and development can be created for experiential learning. We present a summary of the history, development, and current practices of a leadership APPE that can serve as an example for institutions in the implementation of leadership offerings for student pharmacists.

Keywords: advanced pharmacy practice experience (APPE), experiential education, leadership, student development
\end{abstract}

\section{INTRODUCTION}

There is need to expand and improve curriculum in colleges of pharmacy when it comes to leadership development, and there is support for this as advocated by the American Association of Colleges of Pharmacy (AACP) Argus Commission, the Center for the Advancement of Pharmacy Education (CAPE), and the Accreditation Council on Pharmacy Education (ACPE) ${ }^{1-3}$ Current pharmacy literature informs of the need for additional professional development of leadership skills to advance the profession. ${ }^{4-5}$ Fortunately, pharmacy leadership forerunners have developed guiding principles and competencies to assist curriculum committees and instructors in the refinement of curricula ${ }^{6-7}$ This promotion has resulted in deliberate integration of student leadership development courses, specialty tracks, residencies, and programs in the core and elective curriculum of many colleges of pharmacy. ${ }^{8-16}$ These courses and programs include leadership content and assessments to increase self-awareness, relationship management, team-building, and more. ${ }^{17-21}$ Many colleges of pharmacy also offer specialty Advanced Pharmacy Practice Experiences (APPEs). Specialty APPE topics have included entrepreneurship, advanced community practice, clinical practice, and administration. ${ }^{22-24}$ Still, APPE reports regarding achievement of CAPE Outcomes in leadership, innovation, and entrepreneurship are notably absent. ${ }^{24}$ Examples of leadership APPEs would be beneficial to schools or colleges of pharmacy to meet accreditation standards and outcomes, but the literature lacks models to replicate.

The University of Oklahoma College of Pharmacy (OUCOP) has a Leadership Degree Option (LDO) specialty track that consists of five elective courses and two associated APPE rotations, totaling 17 credit hours of course work that students complete over three years. The two LDO APPE rotations include one individual, student-selected leadershiprelated APPE, and the remaining APPE is held during the month of September and includes the cohort of all current fourth-year pharmacy LDO students. The LDO APPE involving this cohort is a month-long, selective, non-patient care rotation at the OUCOP designed specifically for the specialty track. This APPE is designed to build upon the two previous years of didactic classroom coursework completed in the LDO by engaging students in content and activities to practice, 
refine, and further develop leadership skills and experiences. The APPE activities require students to integrate and apply learning from their didactic classroom coursework in leadership to build relationships, solve organizational problems, and model effective leadership behavior. Below presents a summary of the five-year development of a leadership APPE which involved identifying and implementing rich practical experiences to facilitate leadership training and skills-building. This educational brief describes our experience of implementing a leadership-focused APPE to fourth-year pharmacy students in a LDO track, gives examples of content and activities included in the APPE, and provides student evaluation of the APPE.

\section{METHODS}

The key concepts for creating a leadership APPE focus on leadership development standards and recommendations from AACP, CAPE, and ACPE. Personal and professional development aims for pharmacy students include increasing self-awareness, demonstrating responsibility for completing goals, developing relationships, communicating effectively, empowering others, and more. The OUCOP LDO, including the leadership APPE, currently addresses these personal and professional development aims advocated by pharmacy education organizations.

Prior to the LDO APPE, the LDO students completed and reviewed various assessments including Myers-Briggs Type Indicator (MBTI), Thomas Kilmann Instrument (TKI) Conflict Resolution Styles, Emotional Intelligence, and Strengths Finder ${ }^{\circledR}$, participated in group and individual projects, and completed nine credit didactic classroom hours of LDO course content. The didactic content is integrated and is reinforced with each experience and activity scheduled during the APPE month. First implemented in 2012, the month-long LDO APPE originally existed primarily in a contentdelivery format complemented with discussion of case studies on leadership. In our inaugural offering of the leadership APPE, students would spend three to eight hours each day receiving leadership development lectures and presentations with the remaining time spent working on team projects. Although students reported overall satisfaction with the LDO Program, leadership APPE coordinators recognized a need to create a more engaging APPE experience based on the integration of active-learning strategies and other experiential modalities. ${ }^{25-28}$ Over the years, LDO faculty coordinators completed several professional development courses and certifications in leadership. LDO coordinators annually introduced experiences to the APPE they learned from their respective personal and professional development activities. LDO content evolved to include more topics offered in an experiential format - both individual and group experiences. As the LDO APPE developed, we added experiential activities and components to complement previous LDO didactic classroom material, and replaced topics in the APPE that were content delivery-oriented with experiential activities. This led to a shift toward more experiential learning. A brief description of activities of the 2019 leadership APPE month is shown in Table $1 .{ }^{29-42}$ Details regarding the LDO APPE learning objectives and how this content relates to Cognitive Domains of Bloom's Taxonomy and supports achievement of current ACPE and CAPE Outcomes is shown in Table 2.

All APPE rotations at the OUCOP are evaluated using a standardized student evaluation. As LDO coordinators continued to develop the LDO APPE, and given the unique nature of the leadership rotation being a non-patient care experience, a need was identified to elicit additional student feedback regarding the leadership rotation to complement the standard APPE evaluation form. Such an evaluation was conducted on the 2017 LDO graduate cohort by adding the College's standard course evaluation that students voluntarily complete at the end of didactic classroom courses. The survey was administered at the end of the APPE rotation in which students were allotted time on the last day of the rotation to complete the 23-item survey. Evaluation items are structured as a 6-point Likert-type scale: 1) strongly disagree; 2) disagree; 3) undecided; 4) agree; 5) strongly agree; and 6) not applicable. Course evaluation data were analyzed using SASv9.4 and reported as means of agreement.

Two survey items are open-ended response items. These items were: 1) Please provide constructive comments about the course [APPE]; and 2) Please provide constructive comments about the instructor(s). Student responses were aggregated into reviewable documents that were assessed by three researchers using latent thematic analysis. Analysts individually identified nodes by several factors: the frequency with which comments were said, specificity of detail, and extensiveness of response. These nodes were then grouped into similar themes and subthemes. Themes and subthemes were then compared, revised, and edited by all analysts until agreement on saturation of data was achieved.

\section{RESULTS}

The most recent evaluation data for a graduating cohort of LDO APPE students $(n=17)$ with $14(82.4 \%)$ total respondents is reported here. Overall, the students positively agreed with all APPE evaluation items. No item received a response of "Not Applicable." The following survey items had the highest mean agreement: 1) early course [didactic classroom] concepts were reinforced or repeated in the course [APPE] (4.9); 2) relevance of the course [APPE] to my career as a future pharmacist or practice of pharmacy was discussed $(4.8) ; 3)$ the course [APPE] objectives facilitated my learning (4.7); and 4) the course [APPE] used a variety of teaching methods to help me learn and apply my knowledge to 
future practice (4.7). There was only one response of disagreement specific to the organization of the structure of course [APPE] content.

The two categories of free response questions elicited comments regarding the overall APPE and course faculty. In thematic analysis of the free response data, there were five main themes and eleven subthemes created. Comments about the overall course revealed three main themes of Gratitude, Development, and More Connection. The theme of Gratitude included two subthemes - opportunity and experience. Students stated that the Leadership APPE was "an incredible opportunity for (their) pharmacy career". Students also shared that they "wished all other students could experience" the Leadership APPE. The theme of Development included two subthemes - personal/professional growth and leadership skills. Students mentioned that the APPE was "instrumental in (their) personal and professional development" regarding public speaking, relationships, and focusing on values. Students also stated that "the APPE provided me with tools to continue my leadership development" beyond the rotation. The theme of More Connection consisted of the subtheme - structure. Students expressed that the structure of the APPE "was somewhat unorganized" thematically and could benefit from rearrangement of content and experiences. The students also expressed concern about the relevance of some content and activities to leadership development.

Comments regarding the course faculty exhibited two main themes of Influence and Competence. The Influence theme included four subthemes - positivity, inspirational, insightful, and appreciative. Students shared that instructors "made the experience positive" and that they "appreciate the efforts of instructors" to make the course [APPE] a great experience. The Competence theme was present in two subthemes - valuable resource and mentor/guide. Students expressed that instructors made an effort to provide "leadership guidance and mentorship" in a personal manner that exceeded expectations of strictly delivering course content.

\section{DISCUSSION}

This manuscript describes the structure and continuous ongoing development of the OUCOP LDO APPE as well as student perceptions of the month-long leadership rotation experience. The leadership APPE had high levels of agreement among students in evaluation of their experience, comments regarding the overall course benefits, and remarks of faculty. Other APPE and elective program examples in the literature have reported similar findings regarding leadership skills and competencies. ${ }^{11-15}$

Our students who completed the leadership APPE shared a theme that is sparsely reported in pharmacy literature - a sense of gratitude. Our use of open-ended comments to collect student feedback was valuable in identifying the impact leadership development can have on gratitude, emphasizing the importance of its inclusion in pharmacy curriculum. Examples of personal and professional development content have been shown in the pharmacy literature. ${ }^{11-15,19-21,23-24}$ However, the findings in this project are unique as these forms of development occurred in a leadership APPE.

Our students' comments regarding influence of faculty in the leadership APPE reflect similar findings of a leadership elective instructed by graduate students. ${ }^{43}$ There may be a relationship with feelings of inspiration and positivity while receiving leadership content for the purpose of self-development. These thoughts may also contribute to pharmacy student recognition of faculty competency. The provision of skills and leadership tools for development position faculty as a valuable resource for students. Similarly, acknowledgement of faculty as mentors and guides can be attributed to the overarching goal of our leadership APPE to provide specific experiences to students for individualized leadership development.

Our results reported here reflect students' evaluation of the APPE. It also is important to address how faculty coordinators evaluate student learning in the various APPE activities. All APPE rotations in the College are graded on a pass/fail system. As such we evaluate each student's completion of the leadership APPE activities on a pass/fail method based on attendance, participation and contribution to activities, submission of written self-reflections, and student ability to demonstrate their learning experience on the leadership APPE to previous leadership didactic classroom content in the LDO.

Finally, considering we should aspire for all student pharmacists to achieve CAPE outcomes regarding leadership, we offer pearls from our observations and experience so others may adapt content into their respective APPE curricula for students who may not have an opportunity for completing a leadership-focused APPE. Primarily, preceptors can review assessments with students such as strengths, personality preferences, conflict resolution styles, and other tools at the start of an APPE to increase student self-awareness. Throughout the duration of the APPE, preceptors can ask students to reflect on ways or give specific examples of how strengths, emotional intelligence, personality, or conflict resolution presented during interactions with other health care professionals and patients. Preceptors can emphasize the importance of putting leadership in action when working on a health care team for the purpose of increasing one's capacity to build relationships and ultimately deliver optimum patient care. 


\section{CONCLUSION}

An elective APPE with a primary purpose of leadership training and development can be created for experiential learning, and continually be reviewed for the purpose of quality improvement. This manuscript presents a summary of the history, development, and current practices of a leadership APPE that can serve as an example for institutions in the implementation of similar structured leadership programs for student pharmacists.

\section{ACKNOWLEDGMENTS} analysis.

The authors wish to thank and acknowledge Philip Looper, MS, PharmD for his assistance with qualitative data

\section{REFERENCES:}

1. Raehl CL, Baldwin JN, Carter RA, Crabtree BL, Yanchick VA, Maine LL. Game changers in education and health care: report of the 2012-2013 Argus Commission. Am J Pharm Ed. 2013;77(10):Article S18.

2. Medina MS, Plaza CM, Stowe CD, et al. Center for the Advancement of Pharmacy Education 2013 educational outcomes. Am J Pharm Educ. 2013;77(8):Article 162.

3. Accreditation Council for Pharmacy Education. Guidance for the accreditation standards and key elements for the professional program in pharmacy leading to the Doctor of Pharmacy degree. https://www.acpe-accredit.org/pdf/ GuidanceforStandards2016FINAL.pdf. Accessed January 2, 2021.

4. Waddell JJ, Hale AR, Nissen LM. Advanced pharmacy practice and leadership. RSAP. 2016;12(4):662-663.

5. Cox CD. Quantity vs quality in experiential education. Am J Pharm Ed. 2016;80(3):Article 36.

6. Traynor AP, Boyle CJ, Janke KK. Guiding principles for student leadership development in the doctor of pharmacy program to assist administrators and faculty members in implementing or refining curricula. Am J Pharm Ed. 2013;77(10):Article 221.

7. Janke KK, Traynor AP, Boyle CJ. Competencies for student leadership development in doctor of pharmacy curricula to assist curriculum committees and leadership instructors. Am J Pharm Ed. 2013;77(10): Article 222.

8. Cole JD, Dell KA. Implementation and effectiveness of a didactic pharmacy leadership elective. Curr Pharm Teach Learn. 2016;8(5):708-714.

9. Islam MA, Chen G, Talukder R. Specialty tracks in Pharm.D. curricula of US colleges and schools of pharmacy. Curr Pharm Teach Learn. 2016;8(6):774-781.

10. Feller TT, Doucette WR, Witry MJ. Assessing opportunities for student pharmacist leadership development at schools of pharmacy in the United States. Am J Pharm Ed. 2016;80(5):Article 79.

11. Janke KK, Nelson MH, Bzowyckyj AS, Guentes DG, Rosenberg E, Dicenzo R. Deliberate integration of student leadership development in doctor of pharmacy programs. Am J Pharm Ed. 2016;80(1):Article 2.

12. Saleem F, Hassali MA, Aljadhey H, Khan AH, Ahmad FUD. A study evaluating leadership skills among pharmacy students at Universiti Sains Malaysia. RSAP. 2014;10(5):e4-e5.

13. Mort JR, Strain JD, Helgeland DL, Seefeldt TM. Perceived impact of a longitudinal leadership program for all pharmacy students. Innov Pharm. 2014;5(3):Article 167.

14. Bartelme KM, Bzowyckyj A, Frueh J, Speedie M, Jacobson G. Experience and outcomes of a pharmaceutical care leadership residency program. Innov Pharm. 2014;5(3):Article 168.

15. Patterson BJ. Chang EH, Witry MJ, Garza OW, Trewet CB. Pilot evaluation of a continuing professional development tool for developing leadership skills. RSAP. 2013;9(2):222-229.

16. Arnall J, Johnson P, Lee J, Linder M, Lund N, Satpathy S. Student perspectives on student leadership development programs. Am J Pharm Ed. 2014;78(4):Article 85.

17. Allen GP, Moore WM, Moser LR, Neill KK, Sambamoorthi U, Bell HS. The role of servant leadership and transformational leadership in academic pharmacy. Am J Pharm Ed. 2016;80(7):Article 113.

18. Nelson MH, Fierke KK, Sucher BJ, Janke KK. Including emotional intelligence in pharmacy curricula to help achieve CAPE outcomes. Am J Pharm Ed. 2015;79(4):Article 48.

19. Janke KK, Farris KB, Kelley KA, et al. StrengthsFinder signature themes of talent in doctor of pharmacy students in five Midwestern pharmacy schools. Am J Pharm Ed. 2015;79(4):Article 49.

20. Hall CM, Murphy Enright S, White SJ, Allen SJ. A quantitative study of the emotional intelligence of participants in the ASHP Foundation's Pharmacy Leadership Academy. Am J Health-System Pharm. 2015;72(21):1890-1895.

21. Pyhtila JI, Tofade TS, Beardsley RS. Usefulness of reflective journals in a continuing professional development process for a pharmacy leadership course. Pharm Ed. 2014;14(1):129-135.

22. Thomas MC, Sun S. Advanced pharmacy practice experiences for pharmacy students in emergency department settings. Curr Pharm Teach Learn. 2015;7(3): 378-381. 
23. Hester EK, Carroll DG, Kelley KW, Westrick SC. Implementation and evaluation of evidence-based patient care application during a primary care advanced practice experience. Curr Pharm Teach Learn. 2015;7(3):324-331.

24. Dennis VC, May DW, Kanmaz TJ, Reidt SL, Serres ML, Edwards HD. Pharmacy student learning during advanced pharmacy practice experiences in relation to the CAPE 2013 outcomes. Am J Pharm Ed. 2016;80(7):Article 127.

25. Looper PE, Smith MJ, Wilson JE, George DL. Student satisfaction with a Leadership Degree Option program. Poster Presentations. American Association of Colleges of Pharmacy Annual Meeting in Nashville, TN on July 17, 2017.

26. Lucas KH, Testman JA, Hoyland MN, Kimble AM, Euler ML. Correlation between active-learning coursework and student retention of core content during advanced pharmacy practice experiences. Am J Pharm Ed. 2013;77(8):Article 171.

27. Stewart DW, Brown SD, Clavier CW, Wyatt Jarrett. Active-learning processes used in US pharmacy education. Am J Pharm Ed. 2011;75(4):Article 68.

28. Allen RE, Copeland J, Franks AS, Karimi R, McCollum M, Riese II DJ, Lin AYF. Team-based learning in US colleges and schools of pharmacy. Am J Pharm Ed. 2013;77(6):Article 115.

29. Wang C, Burris MA. Photovoice: concept, methodology, and use for participatory needs assessment. Health Educ Behav. 1997;24(3):369-87.

30. Sutton-Brown CA. Photovoice: A Methodological Guide. Photogr Cult. 2014;7(2):169-185.

31. Wilson JE, Smith MJ, Lambert TL, George DL, Buckley C. A novel use of photovoice methodology in a leadership APPE and pharmacy leadership elective. Curr Pharm Teach Learn. 2017;9(6):1042-1054.

32. Loehr J, Schwartz T. The making of a corporate athlete. Harv Bus Rev. 2001;79(1):120-8, 176.

33. Loehr JE, Schwartz T. The power of full engagement: managing energy, not time, is the key to high performance and personal renewal. New York: Free Press; 2005.

34. Burns JMG. Leadership. New York: Perennial; 2009.

35. Vallerand RJ. On the psychology of passion: in search of what makes people's lives most worth living. Can Psychol. 2008;49(1):1-13.

36. Zawadzki MJ, Smyth JM, Costigan HJ. Real-Time Associations Between Engaging in Leisure and Daily Health and Well-Being. Ann Behav Med. 2015;49(4):605-615.

37. Searle JR. Expression and meaning: studies in the theory of speech acts. Cambridge, Eng.: Cambridge University Press; 1989.

38. Davis DM, Hayes JA. What are the benefits of mindfulness? A practice review of psychotherapy-related research. Psychotherapy. 2011;48(2):198-208.

39. Hülsheger UR, Alberts HJEM, Feinholdt A, Lang JWB. Benefits of mindfulness at work: The role of mindfulness in emotion regulation, emotional exhaustion, and job satisfaction. J Appl Psychol. 2013;98(2):310-325. doi:10.1037/a0031313.

40. Dane E. Paying Attention to Mindfulness and Its Effects on Task Performance in the Workplace. J Manage. 2010;37(4):997-1018. doi:10.1177/0149206310367948.

41. Boesen KP, Herrier RN, Apgar DA, Jackowski RM. Improvisational Exercises to Improve Pharmacy Students' Professional Communication Skills. Am J Pharm Ed. 2009;73(2):35.

42. St. John D, St. John P. PeoplePack Dynamics: Unleash the Natural Energy of People and Teams. CreateSpace Independent Publishing Platform; 2015.

43. Patterson BJ, Garza OW, Witry MJ, Chang EH, Letendre DE, Trewet CB. A leadership elective course developed and taught by graduate students. Am J Pharm Ed. 2013;77(10):Article 223. 
Table 1. Descriptions of Individual and Group Activities in the Leadership Degree Option APPE rotation

\begin{tabular}{ll}
\hline $\begin{array}{l}\text { Individual Experience } \\
\text { PhotoVoice }\end{array}$ & $\begin{array}{c}\text { Description } \\
\text { Students present their personal leadership principles to the cohort through } \\
\text { photovoice methodology - critical analysis of an original photograph. }\end{array}$ \\
Power of Full Engagement ${ }^{32-33}$ & $\begin{array}{l}\text { Following a portion of didactic content on the ultimate performance state, } \\
\text { students develop a vision for their life plans based on spiritual, mental, } \\
\text { emotional and physical capacities. }\end{array}$
\end{tabular}

Transformational Leadership ${ }^{17,34}$

Through a series of lessons, students are introduced to the framework of transformational leadership and discuss real-world applications for this specific leadership style.

What's Your Passion? ${ }^{35-36}$

Students self-select an activity that they are passionate about and are designated time for creativity and self-improvement.

Public Speaking

Following didactic content on effective and confident communication, students practice public speaking skills by presenting a five-minute speech on a topic of their choice.

Post Graduate Opportunities Seminar

Course coordinators summarize and present information regarding opportunities available following the completion of the Pharm.D. program.

\section{Group Experience Speech Acts ${ }^{37}$ \\ Mindfulness Retreat ${ }^{38-40}$ \\ Group Projects \\ Improvisation $^{41}$ \\ PeoplePack Dynamics ${ }^{42}$}

Rowing

LDO Graduate Seminar

\section{Description}

Students develop and present personal leadership declarations using language principles from John Searle's speech-act theory.

Students attend a one-day retreat to practice a diverse set of mindfulness exercises including breathing, moving meditation, and mindful eating.

Projects reflecting the needs of the college and community are selected by groups of students. The students use skills learned throughout the Leadership APPE to develop and present their work.

Students attend a 3-hour improvisation session with a local acting coach to improve communication, creative thinking, and public speaking skills.

Groups of students work to recognize energy signatures and use them to improve the working dynamics of their teams in a one-day seminar hosted by the founder and author of PeoplePack Dynamics.

The cohort practices team management and problem-solving while rowing a 20-person dragon boat during an afternoon on the Oklahoma River at the Rowing Olympic Training Facility in Oklahoma City.

Alumni of the Leadership APPE return to the college to share their practical experiences with leadership in the workplace. Students seek advice regarding life after pharmacy school. 
Table 2. Exhibit of how the Leadership Degree Option APPE Learning Objectives meet the 2013 Center for the Advancement of Pharmacy Education (CAPE) Educational Outcomes and the Cognitive Domains of Bloom's Taxonomy

\begin{tabular}{|c|c|c|}
\hline Learning Objectives & $\overline{\text { CAPE }}$ & $\begin{array}{c}\text { Bloom's } \\
\text { Taxonomy }\end{array}$ \\
\hline $\begin{array}{l}\text { Apply various leadership methods/approaches to addressing human } \\
\text { behaviors in an organizational setting }\end{array}$ & $4.2,4.4$ & Ap \\
\hline Describe three energy signatures of individuals & 4.1 & $\mathrm{~K}, \mathrm{C}$ \\
\hline Identify the energy signature of each individual in working groups & $3.6,4.2$ & $\mathrm{~K}, \mathrm{C}$ \\
\hline $\begin{array}{l}\text { Describe the role of each energy signature in relation to group } \\
\text { organizational dynamics }\end{array}$ & $3.6,4.2$ & Ap, An \\
\hline $\begin{array}{l}\text { Apply knowledge of strengths, personality styles, conflict resolution, and } \\
\text { emotional intelligence in managing organizational behavior }\end{array}$ & $3.6,4.1,4.2,4.4$ & Ap, An \\
\hline Describe energy sources for the human body & 2.3 & $\mathrm{~K}, \mathrm{C}$ \\
\hline Practice rituals for managing energy & 2.3 & Ap \\
\hline Engage in the practice of mindfulness & 2.3 & Ap \\
\hline $\begin{array}{l}\text { Complete a project as assigned that supports a programmatic need for the } \\
\text { College of Pharmacy }\end{array}$ & $4.2,4.4$ & $\mathrm{~S}, \mathrm{E}$ \\
\hline $\begin{array}{l}\text { Present a verbal presentation describing how leadership practice related to } \\
\text { completion of the rotation project }\end{array}$ & $3.6,4.2$ & Ap, An, S, E \\
\hline $\begin{array}{l}\text { Write a self-reflection that describes how your professional and personal } \\
\text { experiences on the rotation related to your leadership development }\end{array}$ & $1.1,3.6,4.1,4.2$ & Ap, An, S, E \\
\hline
\end{tabular}

Abbreviations: 1.1=Learner; 2.3=Health and Wellness; 3.6=Communication; 4.1=Self-Awareness; 4.2=Leadership; 4.4=Professionalism; $\mathrm{K}=$ knowledge; $\mathrm{C}=$ comprehension; $\mathrm{Ap}=$ application; $\mathrm{An}=$ analysis; $\mathrm{S}=$ synthesis; $\mathrm{E}=$ evaluation 